\title{
IMÁGENES AMERICANISTAS EN EL SAN IGNACIO DE LOYOLA, FUNDADOR DE LA COMPAÑ́́A DE JESÚS, POEMA HEROICO (1666) DE HERNANDO DOMÍNGUEZ CAMARGO
}

La lírica barroca colonial es un discurso poético mestizo en el cual se dan citas otros emblemas de la realidad americana y donde son también otras las unidades ideológico-culturales que contribuyen al proceso de significación de los textos ("lo otro" en tanto en cuanto se aleja de los modelos europeos). Las imágenes americanistas se construyen con elementos propios de la cultura hispanoamericana en ciernes. El San Ignacio de Loyola, Fundador de la Compañía de Jesús, Poema heroico de Hernando Domínguez Camargo denota una preocupación del hablante lírico por la geografía y el paisaje americanos como una expresión de lo indiano versus los cánones del poema barroco europeo. La mención insistente de América y su efecto obsesivo en el discurso es el foco de análisis de este ensayo. Se trata de indagar acerca de su significación en la serie de octavas reales que es el Poema heroico para atisbar la intención del hablante lírico de dignificar el espacio americano como espacio no de calcos sino de originales. Dicho de otro modo: en este estudio se intenta dilucidar la tarea de los poetas coloniales de iniciar una distancia entre Europa y América, entre lo europeo y lo americano, como diferencias conciliatorias, pero diferencias en sí.

En mi reciente libro, El palimpsesto del calco aparente: Una poética del Barroco de Indias inicié el estudio de la poesía camarguiana como especifidad lírica que partiendo del discurso gongorino se aleja de éste en un estadio de superación y se acerca a una poética americanista más allá de copias o de meros calcos. A manera de palimpsesto el Poema heroico exhibe una superación del referente gongorino en referente camarguiano donde el elemento americano prima sobre el europeo haciendo de todo el poema una reflexión sobre América versus Europa.

En el poema "Al agasajo con que Cartagena recibe a los que vienen de España", Domínguez Camargo se refiere a esta ciudad de Indias de la siguiente manera:

Esta, blanco pequeño de ambos mundos,

de veleras saetas asentado, que, vencidos los mares iracundos, a su puerto se proa han destinado: do de Europa, de América fecundos partos le expone aquél, este costado, que al sur remite, al norte se desata la plata en ropas y la ropa en platas. (381) 
En este pasaje se está expresando cómo Cartagena de Indias es el blanco pequeño de esos dos mundos (Europa y América). Esos "partos" a los que se le expone a América son el comercio de la plata o de la riqueza; cómo de una (América), esta riqueza es llevada a la otra (Europa). Esos "partos" son calificados por el hablante lírico como fecundos. La posición geográfica de ambos puntos aparece localizada topográficamente como norte (Europa) y sur (el continente americano) en una subrepticia relación de subordinación de A sobre B.

El Poema heroico, la biografía poética de San Ignacio de Loyola, se inicia con la presencia metafórica de un embajador inca ante la pila bautismal del santo, incorporando al imperio incaico como unidad política de la Ecumene (donde se representa tanto a Oriente como a Occidente), hacia 1491, un año antes del llamado descubrimiento. La siguiente estrofa recoge este aspecto:

El que América en una y otra mina
hijo engendra del sol, oro luciente,
indiana se vistió la clavellina,
y al pie torcido su natal serpiente
(talar su mejor hoja) se destina:
Mercurio de los huertos que, elocuente
(si el caduceo el pie le dio y la copa),
del Inca embajador voló a la Europa. (48)

Vemos que de "Al agasajo con que Cartagena recibe a los que vienen de España" al Poema heroico se sigue insistiendo en la capacidad minera de América. En este pasaje citado se poetiza el oro como "hijo engendra del sol" y esta imagen americanista del primer canto, del libro primero del poema, inicia esa insistencia que es nuestro objeto de estudio: cómo el hablante lírico menciona, comenta, elogia, revela y se regodea en la relación oro o plata/ riqueza /América como medio velado de denuncia del efecto de la Conquista.

Georgina Sabàt-Rivers en su artículo "Interpretación americana de tópicos clásicos en Domínguez Camargo: La navegación y la codicia", añade un importante aspecto político a la hora de estudiar a los poetas del Barroco de Indias como integrantes de una resistencia subrepticia a los centros del poder europeo en su discurso poético. Nos dice Sabàt-Rivers:

Si Góngora había hablado de las riquezas de América... Domínguez Camargo no sólo se ocupa de ellas en su obra sino que señala, aunque de modo oscuro y ambiguo, el expolio [despojo] de que era objeto; hallamos referencia a este motivo cuando menciona el oro del Inca que voló a la Europa. (195)

He aquí el efecto de las imágenes americanistas en el Poema heroico: denunciar subrepticiamente el saqueo español a América. Un rastreo por todo el texto revelaría la insistencia del hablante lírico por referirse a lo indiano en una matriz poética que se repite recogiendo siempre el valor del oro americano y su manipulación y robo por parte del europeo.

En los cinco libros de este poema inconcluso se relata esporádicamente la vida de San Ignacio de Loyola desde su nacimiento, su vida militar, pasando por su conversión y peni- 
tencia hasta la fundación de la Compañía de Jesús. Los críticos han coincidido en considerar el Poema heroico de Domínguez Camargo de varias maneras.

Emilio Carilla comenta lo siguiente sobre la copia o el calco de Góngora a Domínguez Camargo:

Puede decirse que gran parte de las Soledades están calcadas y hábilmente dispuestas a lo largo del poema [Poema heroico]: no faltan ni los banquetes ni la historia de los descubrimientos marítimos (=codicia), ni los juegos atléticos, ni escenas de cetrería. (112)

Alicia de Colombí-Monguió establece la "metáfora acuática" (288) o "el tropos metafórico de lo fluido" que "invade toda realidad en la poesía de Domínguez Camargo" (282) como el elemento específico en su poesía: "El dinamismo de las metáforas... lleva a la fusión de toda entidad en una liquidez que al absorberlo todo, todo lo diluye" (282).

Gerardo Diego se centra en el estudio del verso "dulcemente alabastro fugitivo" que metaforiza la leche quedando "definida poéticamente, creada o re-creada en el bellísimo endecasílabo de tres palabras fundidas con violenta sintaxis latina según el procedimiento de Góngora" (291). Diego comenta sobre la anécdota que se pierde en la vida del santo fundador de la Compañía de Jesús: “...la poesía aparece aquí y se sumerge allá, y en cuanto al interés anecdótico, a la amenidad del relato, naufraga con frecuencia anegada por la balumba culterana del ornato frondoso" (300).

Ester Gimbernat de González insiste en la falta de línea argumental en el poema o la ausencia de anécdota:

Lo que desconcierta desde la primera línea del poema es que la biografia, que en un comienzo parece ser el eje motor de la construcción se vuelve paulatinamente un recurso. Es decir, se va despojando de su papel central, que la propondría como fin en sí misma, para convertirse en pretexto de la narración. (524)

Giovanni Meo Zilio, por otro lado, señala cómo se imita para crear, re-hacer, re-crear en una abstracción hiperbarroca donde se desintegra el modelo gongorino para reintegrarlo en otro original:

No se trata nunca de una mera imitación textual inerte, sino de utilización de varios (y numerosos) elementos eidéticos (léxicos y/o rítmicos) entresacados de Góngora, mezclados luego como naipes (desintegrándose la estructura sintáctica o fantástica originaria) y vueltos a ordenar de otra manera, personalísima (reintegrándose las estructuras según esquemas originales). (319)

Las especifidades camarguianas han sido vistas por la crítica como la ramificación metafórica junto a la variedad métrica necesaria (para apartarse de los modelos), y el tropos o la metáfora acuática y dinámica (que pretende fundir las entidades absorbiéndolo todo en el discurso) (Carilla y Colimbí-Monguió). Se ha considerado cómo el regodeo lírico y la anécdota que se pierde (o ese "moroso devenir") instan al abandono de una línea argumental decisiva en la historia del santo (Diego y Gimbernat de González). Se ha señalado cómo se 
imita para crear, re-hacer, re-crear en una abstracción hiperbarroca donde se desintegra el modelo gongorino para reintegrarlo en otro original camarguiano (Meo Zilio).

A la luz de estas consideraciones críticas se pueden analizar las imágenes americanistas en el poema, partiendo de una contextualización, en la cual, éstas se lean como ramificaciones metafóricas en consonancia con el regodeo que permea todo el texto en el abandono deliberado de la anécdota en aras de otros propósitos. En este caso, se denuncia veladamente la condición colonial de América. Aquí se desintegraría el original gongorino reintegrándolo en otro original camarguiano. Podría decirse que las imágenes americanistas denotan la posición de resistencia del intelectual americano frente al proceso de colonización. De ahí el que sea necesario rescatar al Barroco de Indias como un movimiento poético de calcos aparentes y diferencias desde las cuales ese gongorismo indiano es el proyecto cultural que madurará hacia el proyecto político de las guerras de Independencia del siglo XIX durante el Romanticismo hispanoamericano. Este argumento es desarrollado por Mabel Moraña en su estudio "Barroco y conciencia criolla en Hispanoamérica":

La importancia del Barroco reside principalmente, por un lado, en que la evaluación de esa producción poética plantea problemas crítico-historiográficos que se proyectan sobre todo el desarrollo posterior de la literatura continental, y que derivan del proceso de imposición cultural y reproducción ideológica que acompañó a la práctica imperial. En segundo lugar, es también en el contexto de la cultura barroca que aparecen las primeras evidencias de una conciencia social diferenciada en el seno de la sociedad criolla. Esas formas incipientes $-\mathrm{y}$ en muchos casos contradictorias- de conciencia social, hablan a las claras, sin embargo, de la dinámica creciente de las formaciones sociales de ultramar, y no es errado ver en ellas el germen, aún informe, de las identidades nacionales. (231)

No se trata de que el poeta copie en su discurso, sino más bien de que calque y que produzca un original sin aparentes huellas de la Metrópoli. Severo Sarduy ha desarrollado una lectura sobre el Barroco como movimiento estético del siglo XVII que es pertinente considerar para entender el alcance de la relación de original/copia/calco, condición del poema barroco hispanoamericano. Asevera Sarduy que del Barroco de Indias hay que hacer una lectura en filigrana, es decir, las obras de este movimiento literario suponen la re-escritura o re-elaboración de textos que le preceden, pero en una tentativa de originalidad o de distanciamiento de los modelos. Dice Sarduy:

Sólo en la medida en que una obra del Barroco latinoamericano sea la desfiguración de una obra anterior que haya que leer en filigrana para gustar totalmente de ella, ésta pertenecerá a un género mayor; afirmación que será cada día más valedera, puesto que más vastas serán las referencias y nuestro conocimiento de ellas, más numerosas las obras en filigrana, ellas mismas desfiguración de otras obras. (175)

El Poema heroico sería un corpus concreto en el cual verificar este fenómeno de criollismo temprano a través de su denuncia casi velada de la situación del oro expoliado (despojado) de las Américas. Mediante el uso de la metáfora gongorina de factura camarguiana, estaríamos frente a una voz poética de resistencia, quien inocente y aparentemente, cuenta 
sólo y de pasada la vida de San Ignacio. Podríase aventurar la teoría de que ese "moroso devenir" calificado por Gimbernat de González es una estrategia textual del débil o del criollo para denunciar el efecto de la conquista, la colonización y el asentamiento del imperio español en el suelo americano.

La mención insistente de Potosí, la montaña boliviana tótem de la riqueza extraordinaria de las minas de oro y plata. enmarca el discurso poético en la diatriba culterana de nombrar aquello que se quiere, en este caso oro/plata, por medio de otro vocablo: Potosí. De este modo la alusión al término evidencia la conciencia del hablante lírico frente a la empresa colombina. En los cinco libros que componen el texto son recurrentes octavas reales donde la relación Potosí/riqueza es clara y donde la mención de la plata es directa. Veamos un ejemplo:

Con blanco alterno pecho le flechaba

Madre amorosa, tanto como bella, de la una y otra ebúrnea blanda aljaba de blanco néctar una y otra estrella; y su labio el pezón solicitaba, si en blanca nube no, dulce centella, en aquel Potosí de la hermosura, venas, de plata no, de ambrosía pura. (43)

En esta octava real se narra la lactancia del niño y se le iguala al seno de la madre con el "Potosí de la hermosura". Se está autentificando el oro y la plata americanos con los senos de la madre de San Ignacio de Loyola. No siendo ya sólo de plata sino de "ambrosía pura".

Las imágenes americanistas irrumpen como telón de fondo para ubicar la biografia del santo fundador de la Compañia de Jesús y son el soporte del aspecto ideológico a través del cual el hablante rastrea en todo el poema el efecto de lo indiano en el discurso europeo. Es decir, la vida de San Ignacio serviría sólo de pretexto para presentar al espacio americano, en el cual se ha efectuado el despojo por parte de España:
Augusto así garzón, pisó los lares
de la corte de césares hispanos,
que de fortuna son en altos mares
coronados Caribdis soberanos:
donde en náufragos votos, los altares
de ídolos fatiga cortesanos
indiana nao, que en preciosa suma,
carga de oro por cargar de espuma. (60)

Esta octava real exhibe el acusado imperialismo hispánico ("de la corte de césares hispanos") que veladamente el hablante destaca por todo el Poema heroico. La indiana nao que carga oro en lugar de espuma es otro elemento en el cual el hablante se detiene casi de pasada en el moroso devenir de los acontecimientos de la vida del santo para con la comparación de oro /espuma especificar los desmanes de los españoles en la empresa de conquista. Recor- 
demos que los jesuitas (soldados de Cristo con la espada y con la fe) fueron óptimos representantes del paradigma del Conquistador y de la colonización en general.

Los cinco libros inconclusos del poema narran: el bautismo, la niñez del santo junto con su período de Capitán en Pamplona, pasando por los milagros que marcan su vida (la visita de San Pedro quien lo sana de sus heridas), su conversión, penitencia, sus peregrinaciones a Roma, Génova, Venecia, Jerusalem, su vuelta a España, sus estudios y perfecciones hasta la junta de discípulos y su inicio de la Compañía. Un análisis orgánico de los regodeos poéticos en los que se pierde esta anécdota podría develar una posible unidad de lectura de todo el Poema heroico como un texto seudosubversivo desde los márgenes de un grupo de intelectuales del siglo XVII que plantean un proyecto de diferenciación estética frente a la Metrópoli, pero que, a su vez, contiene la denuncia velada de los desmanes de la colonia española en América.

Es claro que autores como Sor Juana Inés de la Cruz con su poema El Sueño (1692), Juan del Valle y Caviedes con su Diente del Parnaso (1689) o don Carlos de Sigüenza y Góngora con su Primavera indiana (1662) o su Teatro de virtudes políticas que constituyen a un príncipe (1680) han de criticar las instituciones que no permiten al criollo ni al mestizo participar políticamente en el medio cultural y político de la Nueva España o la Nueva Granada como espacios ya diferenciados de lo europeo.

Sin embargo, curiosamente, esta denuncia se hace con un estilo europeo como lo es el Barroco, pero "apropiado" en lo que don Mariano Picón Salas etiquetó como Barroco de Indias. Estilo donde es la figura retórica de la elipsis el mecanismo mediante el cual se subtiende la imagen, donde no se dice directamente sino subrepticiamente aquello que se le plantea a los lectores cultos e iniciados del movimiento: la fiebre del oro y de la plata de los colonizadores que continúa en la colonia hasta avanzado el siglo XVII.

Como conclusión preliminar quedaría abierta una puerta para indagar acerca de otros textos como el San Ignacio de Loyola, Funadador de la Compañía de Jesús, Poema heroico, donde el hablante lírico estratégicamente compone sus versos como bastiones de resistencia ante la Metrópoli europea. Imágenes americanistas como ésta de Potosí/riqueza develada aquí nos llevarían a extender una lectura mucho más abarcadora a otros discursos poéticos del XVII en América donde el recurso del poema barroco esclarese, en su aparente oscuridad, la denuncia de la posición del criollo y del débil en los mecanismos del poder colonial. 


\section{Obras citadas}

CARILla, Emilio: "Hernando Domínguez Camargo", en su:

El gongorismo en América, Buenos Aires, Universidad de Buenos Aires, Facultad de

Filosofia y Letras, Instituto de Cultura Latinoamericana, 1946, pp. 110-122.

DOMÓNGUEZ CAMARgo, Hernando: Obras. Edición a cargo de Giovanni Meo Zilio, Caracas, Ayacucho, 1986.

Colombí-Monguió, Alicia de: "Piélagos de voz: Sobre la poesía de Domínguez Camargo", «Revista de Filología Española», 66 (1986), pp. 273-296.

DIEGO, Gerardo: "La poesía de Hernando Domínguez Camargo en nuevas vísperas.".

«Thesaurus: Boletín del Instituto Caro y Cuervo» 16.2 (1961), pp. 281-310.

GIMBERNAT DE GONZÁLEZ, Ester: "En el espacio de la subversión barroca,

el Poema heroico de H. Domínguez Camargo",

"Thesaurus: Boletín del Instituto Caro y Cuervo», 37.3 (1982), pp. 523-543.

MEO ZILIO, Giovanni: Estudio sobre Hernando Dominguez Camargo y su "Ignacio de

Loyola”, Poema heroico, Messina-Firenze, G. D’Anna, 1967.

MORAÑA, Mabel: "Barroco y conciencia criolla en Hispanoamérica",

«Revista de Crítica Literaria Latinoamericana»14.28 (1988), pp. 229-251.

SABÀT-RIVERS, Georgina: "Interpretación americana de tópicos clásicos en Domínguez

Camargo: La navegación y la codicia”, «Edad de Oro» 10 (1991), pp. 187-198.

SARDUY, Severo: "El Barroco y el Neo-barroco" en: América Latina en su Literatura,

César Fernández Moreno, ed. México, Siglo XXI, 1977, pp. 167-184.

TORRES, Daniel: El palimpsesto del calco aparente: Una poética del Barroco de Indias,

New York, Peter Lang, 1993.

Povzetek

PODOBA AMERIKE V JUNAŠKI PESNITVI O SVETEM

IGNACIJU LOYOLI, USTANOVITELJU JEZUITSKEGA REDA (1666), HERNANDA DOMÍNGUEZA CAMARGA

Članek je kratka študija Junaške pesnitve Hernanda Domíngueza Camarga in sicer njenih političnih razsežnosti. Avtor analizira zgodovino evropskega pohlepa po ameriškem zlatu in srebru oziroma to, kako lirični subjekt pesnitve skoraj neprikrito razgali, kako je Evropa izropala Ameriko in kakšne so bile posledice španskega kolonialnega nasilja v Ameriki. Kolonialni barok, barok pesnikov iz španskih kolonij v Ameriki je torej stil, ki so se ga ti zvito posluževali za skoraj neprikrito kritiziranje matične države. 